\title{
Dissolution Behavior of the Antioxidant in PP in Tap Water and Evaluation of the Polymer Degradation
}

Mio GONOKAMI ${ }^{1 *}$, Yoshito OHTAKE ${ }^{2}$ and Seiichi KAWAHARA ${ }^{1}$ ( ${ }^{1}$; Department of Materials Science and Technology Faculty of Engineering, Nagaoka University of Technology, 1603-1 kamitomioka, Nagaoka, Niigata 940-2188, Japan. ${ }^{2}$; Chemicals Evaluation and Research Institute, Japan, 1600 Shimotakano, Sugito-machi, Kitakatsushika-gun, Saitama 345-0043, Japan)

Use of polypropylene products in tap water decreases its lifetime as compared to in the air. The reason is that antioxidants, which determine polymers' lifetime, dissolve into water rapidly and polypropylene products become easy to deteriorate. Especially, when water contains residual chlorine, polypropylene products generate carbonyl group which shows the oxidation degradation on its surface and this leads to the strength degradation.

(Received on December 8, 2010)

(Accepted on March 25, 2011)

Key Words : Polypropylene, Degradation, Residual Chlorine, Antioxidant, Dissolution, Blooming

\section{1. 緒言}

ポリプロピレン（以下「PP」とする）は第三級炭素を 持つため他のポリオレフィンと比較し劣化しやすいポリマ ーで，光や熱の作用で生成した第三級炭素ラジカルにより 連鎖的に劣化反応が進み, 主鎖切断による低分子化が生じ ぜい弱化する ${ }^{1)}$ 。そのためPP成形品は, 酸化防止剤や紫 外線吸収剤などを添加することで，成形時及び使用時の熱 や光による劣化反応を防いでいる. しかし, 高温多湿や温 水中などの過酷な環境下で使用した場合, 添加剤は熱によ る揮発, 他ポリマーへの移行だけでなく, 溶解度の高いも のは水へ溶出し, その結果, 添加剤が消失したポリマーは 著しく劣化が進行する可能性がある.

我々は水道水環境下における加硫ゴムの水劣化につい て, 老化防止剤の減少原因及び減少量と劣化の関係に着目, 表面もしくはその近傍に存在する老化防止剤などの添加剤 が水中へと溶出, その結果, 水中に含まれる残留塩素など の劣化因子による攻撃を容易に受け，激しい表面劣化を誘 引することを明らかにしている2,3). PP成形品等の樹脂成 形品を水道水環境下で使用した場合も同様の現象が生じ,

1 長岡技術科学大学 工学部 物質 - 材料系

（９９40-2188 長岡市上富岡町 1603-1）

2一般財団法人 化学物質評価研究機構 高分子技術センター所長 高分子技術部

（３45-0043＼cjkstart埼玉県北葛飾郡杉戸町下高野 1600）
水中に存在する残留塩素や熱交換器などから溶出した銅イ オンなどの攻撃により劣化し, さらに実使用時は成形時の 残存ひずみや使用時にかかる水圧により樹脂内部にひずみ が蓄積し, わずかな劣化でもそれが起点となりトラブルを 起こす可能性がある. 市場において樹脂製品を水道水環境 下で使用する場合, 空気中に比べ劣化が著しく, 様々な卜 ラブルが発生している ${ }^{4)}$ 。事実，水道水使用環境下にて 長期間使用したPP成形品は, 酸化防止剤が著しく減少, さらにFigure 1 に示すFT-IRスペクトルではPP表面には 内部に観察されない $1740 \mathrm{~cm}^{-1}$ 付近のカルボニル基の吸 収及び $1650 \mathrm{~cm}^{-1}$ 付近の-C = C-による吸収が確認され,

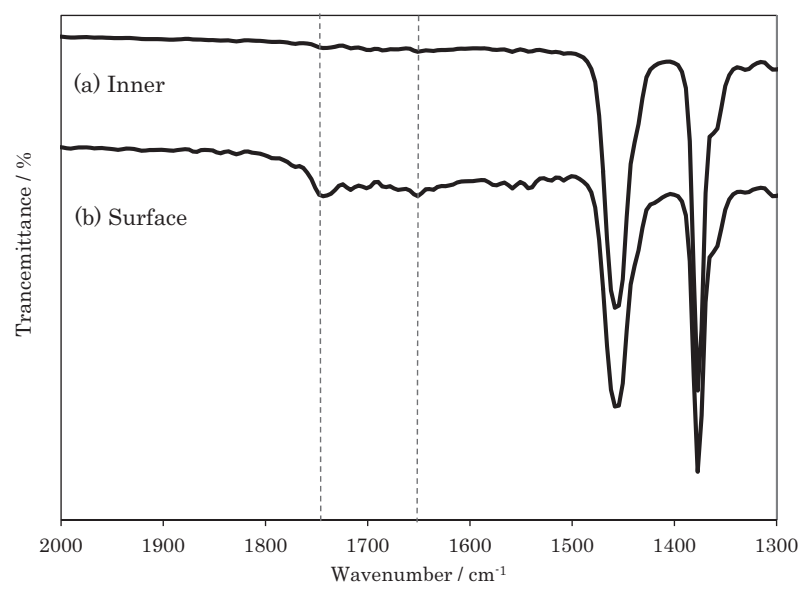

Figure 1 FT-IR spectra of PP product used in tap water for a long term: (a) Inner, (b) Surface 
酸化劣化していた。

本研究では水道水環境下における PP成形品の劣化原因を 明らかにするため, プラスチック成形品において最も多用さ れているフェノール系酸化防止剂及び硫黄系酸化防止剂添 加 $\mathrm{PP}$ 射出成形品について, 水道水環境下を想定した促進処 理を行い酸化防止剂流出量と劣化の関係を調査した。

\section{2. 実}

\section{験}

\section{1 試料}

プライムポリマー製ホモPPにフェノール系酸化防止剂 及び硫黄系酸化防止剂を 0.25 wt \%添加したペレット, 及 び酸化防止剂の流出と劣化の挙動をより明瞭に把握するた め 5 倍量の 1.25 wt \%添加したペレットから厚さ $1 \mathrm{~mm}$ の シートに射出成形し， 2 種類のシートを作製した。

$\mathrm{PP}$ な゙のオレフィン系樹脂では成形及び使用時の酸化 劣化を防ぐためラジカル連鎖禁止剂であるフェノール系酸 化防止剂と過酸化物分解剂である硫黄系酸化防止剂を併用 することが多く，作用機構の異なる酸化防止剂を併用する ことで相乗効果を示すことが知られている ${ }^{5)}$. 本研究では, フェノール系酸化防止剤としてBASF製ペンタエリスリ トールテトラキス [3-（3',5'-ジ-tert-ブチル-4'-ヒドロキシフ エニル）プロピオナート], 硫黄系酸化防止剤としてエー ピーアイコーポレーション製ジオクタデシル 3,3 '-チオジプ ロピオナートを選択した。 Table 1 に作製した試料及び使
用した酸化防止剂を示す。

\section{2 塩素水, イオン交換水での浸せき処理及び熱老化 処理}

水道水使用環境下での PP成形品を想定し, 塩素水によ る浸せき処理を実施した。さらに，残留塩素及び熱の影響 を明確にするためイオン交換水を用いた浸せき処理及び熱 老化処理も併せて実施した. Table 2 に処理条件を示す. 塩素水は劣化促進を考虑し残留塩素濃度を市場よりも高濃 度の $200 \mathrm{ppm}$ とし, 関東化学製塩素水をイオン交換水で 希釈， $\mathrm{NaOH}$ にて $\mathrm{pH}$ を $6.5 \sim 7.0$ に調製した。気密性のあ る容器に試験片と塩素水を封入し, 室温 $\left(23{ }^{\circ} \mathrm{C}\right), 60{ }^{\circ} \mathrm{C}$, $80{ }^{\circ} \mathrm{C}$ に加温した，残留塩素の消費を考慮し，浸せき液は 24 時間毎に交換，できるだけ均一な濃度で新鮮な水道水 と接している環境を再現した。また，同様な条件にてイオ ン交換水による浸せき処理，上島製作所製ギアー式熱老化 試験機を用いた熱老化処理（室温 $\left(23{ }^{\circ} \mathrm{C}\right), 60{ }^{\circ} \mathrm{C}, 80{ }^{\circ} \mathrm{C}$ ) を実施した。また，給水機器などでは繰り返しかかる水圧 により樹脂内部にひずみが蓄積することで劣化促進するこ とを想定し, Figure 2 に示すように試料にひずみを付与し た状態での浸せき処理及び熱老化処理を実施した.

\section{3 PP成形品中の酸化防止剤の定量}

冷凍粉砕した試料をジクロロメタンにて48 時間のクネ

Table 1 Additive amount of antioxidants in PP

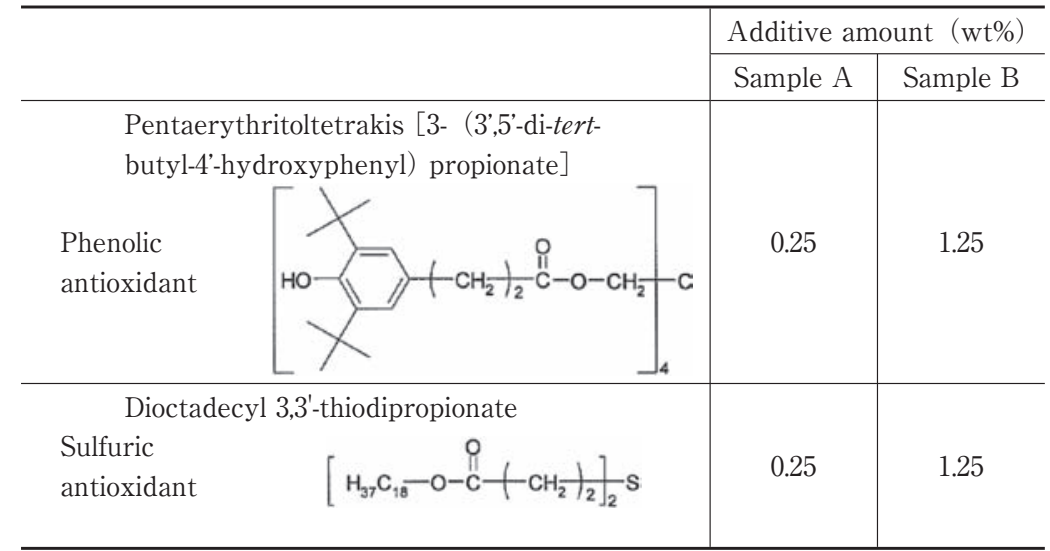

Table 2 Conditions of accelerated degradation treatment

\begin{tabular}{|c|c|c|c|}
\hline & $\begin{array}{l}\text { (a) Immersion treatment } \\
\text { in chlorine water } \\
\text { ("Chlorine water") }\end{array}$ & $\begin{array}{l}\text { (b) Immersion treatment } \\
\text { in ion-exchanged water } \\
\text { ("Ion-exchanged water”) }\end{array}$ & $\begin{array}{c}\text { (c) Air oven aging test } \\
\text { ("Air") }\end{array}$ \\
\hline $\begin{array}{l}\text { Treatment } \\
\text { environment }\end{array}$ & $\begin{array}{c}\text { Chlorine water } \\
\text { (Concentration of residual } \\
\text { chlorine : } 200 \mathrm{mg} / \mathrm{l} \\
\text { pH : } 6.5 \sim 7.0 \text { ) }\end{array}$ & Ion-exchanged water & Gear oven aging tester \\
\hline $\begin{array}{l}\text { Treatment } \\
\text { temperature }\end{array}$ & $\begin{array}{c}\text { Room temperature }\left(23^{\circ} \mathrm{C}\right) \text {, } \\
60{ }^{\circ} \mathrm{C}\end{array}$ & $\begin{array}{c}\text { Room temperature }\left(23{ }^{\circ} \mathrm{C}\right) \text {, } \\
60^{\circ} \mathrm{C}, 80{ }^{\circ} \mathrm{C}\end{array}$ & $\begin{array}{c}\text { Room temperature }\left(23{ }^{\circ} \mathrm{C}\right) \text {, } \\
60{ }^{\circ} \mathrm{C}, 80{ }^{\circ} \mathrm{C}\end{array}$ \\
\hline $\begin{array}{l}\text { Treatment } \\
\text { time }\end{array}$ & $30,60,90$ days & $30,60,120$ days & $30,60,120$ days \\
\hline
\end{tabular}




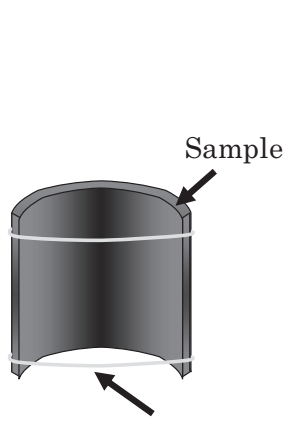

Stainless wire

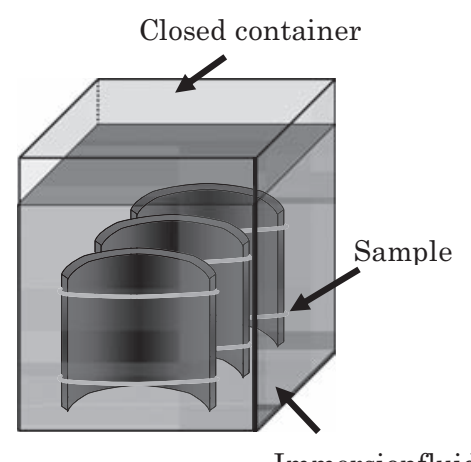

Immersionfluid

Figure 2 State of immersion treatment

フレル抽出を行い，抽出液中の酸化防止剂を定量した。フ エノール系酸化防止剂は抽出液をメタノールに転溶後, HPLC（液体高速クロマトグラフ）にて分析, 硫黄系酸化 防止剂は抽出液を GC-FID （水素炎イオン化検出器付ガス クロマトグラフ）を用いて分析した。

\subsection{PP成形品の機械的強度測定及び劣化評価}

塩素水，イオン交換水による浸せき処理及び熱老化処理 後のPP成形品について Figure 3 に示すようにひずみが与 えられている箇所からスーパーダンベルにてひずみに平行 に試料を採取し, Alpha Technologies社製テンソメータ にて JISK7161に準拠し引張降伏応力を，ひずみの影響が 比較的すくない部分より試料を採取し，島津製作所製精密 万能試験機オートグラフにて JISK6911に準拠し曲げ強さ を測定した。また，動的粘弾性の温度分散から測定温度領 域における材料の剛性を示す貯蔵弾性率が得られるため，レ オメトリックス社製粘弾性測定装置 RSA- III にて JISK7244-4 に準拠し測定周波数 $1 \mathrm{~Hz}$ ，測定温度 $-10 \sim 80{ }^{\circ} \mathrm{C}$ におけ る動的貯蔵弾性率，動的損失弾性率及び損失正接を引張モ ードで測定した．表面劣化による化学構造変化をバイオ・ ラッドラボラトリーズ社FTS-40A 及びUMA-500 顕微鏡 FT-IR（ATR法）にて，さらに，酸化劣化による酸化開 始温度をメトラー社製 TA-3000DSC-30により測定した。

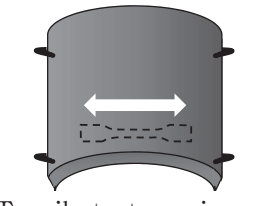

Tensile test specimens (at direction of arrow)

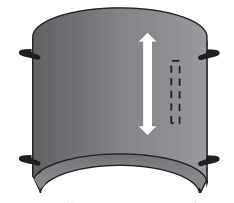

Flexural test specimens (at direction of arrow)
Figure 3 Tensile test specimens and flexural test specimens

\section{3. 結 果と 考 察}

\section{1 表面ブルーム物の分析}

酸化防止剂 $1.25 \mathrm{wt} \%$ 添加したPP成形品では $60{ }^{\circ} \mathrm{C}, 80$ ${ }^{\circ} \mathrm{C}$ の塩素水への浸せき処理及び $80{ }^{\circ} \mathrm{C}$ のイオン交換水への 浸せき処理において試料全体が黄変し，著しいブルームが 認められた.ブルーム物の顕微鏡 FT-IR スペクトルを Figure 4 に，ピークの帰属をTable 3 に示す. フェノール系 酸化防止剂に特有の $\mathrm{OH}$ 伸縮振動に起因する $3700 \mathrm{~cm}^{-1}$ 付 近のピークが確認されないことから，ブルーム物の主成分 は硫黄系酸化防止剤ジオクタデシル 3,3'-チオジプロピオナ ートと判断した。一般に添加剤のブルームはポリマーと添 加剤の相溶性と添加剤の分子量が関係する. 相溶性を表す 指標として溶解度パラメーター（SP值）があり，值が近 い物質は互いによく相溶し，ブルームし難い。また添加剤 の分子量は小さいものほど速くブルームしやすい傾向があ $ろ^{2)}$. Table 4 に添加剤の溶解度パラメーターと分子量及 びPPの溶解度パラメーターを示す。硫黄系酸化防止剂の $\mathrm{SP}$ 值はPPのそれと近く相溶性が良いためブルームし難い が, 処理時の熱で分子運動が活発化し，フェノール系酸化 防止剂よりも分子量の低い硫黄系酸化防止剂がブルームし たものと考えられる．試料表面へのブルームは劣化の保護 膜として㗢き劣化因子の攻撃を防止すると考えられるが実 使用場面では，表面のブルームは流水により物理的に洗い 流されることを考慮し，ブルームの比較的すくない 0.25 wt\%添加品について調査を進めることとした.

\section{2 老化防止剂の減少挙動}

塩素水，イオン交換水による浸せき処理及び熱老化処理

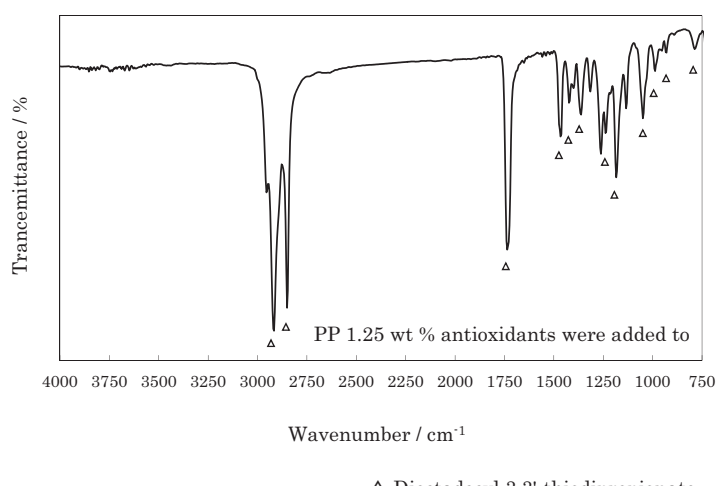

$\triangle$ Dioctadecyl 3,3'-thiodipropionate

Figure 4 FT-IR spectrum of bloom on PP treated by ionexchanged water $\left(60{ }^{\circ} \mathrm{C}\right)$

Table 3 Characteristic absorption bands of PP treated by chlorine water $\left(60{ }^{\circ} \mathrm{C}\right)$

\begin{tabular}{c|c|c|c|c|c|c|c}
\hline Resin & \multicolumn{10}{c}{ Polypropylene } \\
\hline Wave number $\left(\mathrm{cm}^{-1}\right)$ & 2918 & 2850 & 1735 & 1465 & 1363 & 1184 & 721 \\
Absorption band & $v \mathrm{CH}_{2}$ & $v \mathrm{CH}_{2}$ & $v \mathrm{C}=\mathrm{O}$ & $\delta \mathrm{CH}_{2}$ & $\delta \mathrm{CH}_{3}$ & $v \mathrm{C}-\mathrm{O}$ & $\rho \mathrm{CH}_{2}$ \\
\hline
\end{tabular}

$v$ : Stretching vibration, $\delta$ : Bending vibration, $\rho$ : Rocking vibration 
Table 4 Solubility parameter and molecular weight of polypropylene and antioxidants

\begin{tabular}{l|c|c}
\hline & $\begin{array}{c}\text { Solubility } \\
\text { parameter* }\end{array}$ & $\begin{array}{c}\text { Molecular } \\
\text { weight }\end{array}$ \\
\hline Polypropylene & 8.1 & - \\
\hline $\begin{array}{l}\text { Phenolic antioxidant: } \\
\begin{array}{l}\text { Pentaerythritoltetrakis [3- (3','-di-tert-butyl- } \\
\text { 4'-hydroxyphenyl) propionate] }\end{array}\end{array}$ & 11.8 & 1178 \\
\hline $\begin{array}{l}\text { Sulfuric antioxidant: } \\
\text { Dioctadecyl 3,3'-thiodipropionate }\end{array}$ & 8.6 & 683 \\
\hline \multicolumn{2}{|c}{${ }^{*}$ Calculated by small method }
\end{tabular}

後のPP成形品に含まれるフェノール系酸化防止剂含有率 を Figure 5 に，硫黄系酸化防止剤含有率を Figure 6 に処 理前を $100 \%$ とてて示す. 熱老化処理ではフェノール系, 硫黄系ともに酸化防止剤の減少が僅かであるが，イオン交 換水及び塩素水では浸せき時間の増加に伴い酸化防止剂含 有率が減少，その傾向は高温で残留塩素を含む場合がより 著しい。

熱老化処理において酸化防止剤は，空気中への揮発と熱 酸化劣化防止による消費で減少するが，酸化防止剤の融点 はフェノール系で約 $110{ }^{\circ} \mathrm{C}$, 硫黄系で約 $63{ }^{\circ} \mathrm{C}$ と高いため 熱老化処理温度では揮発し難く，熱酸化劣化防止による消

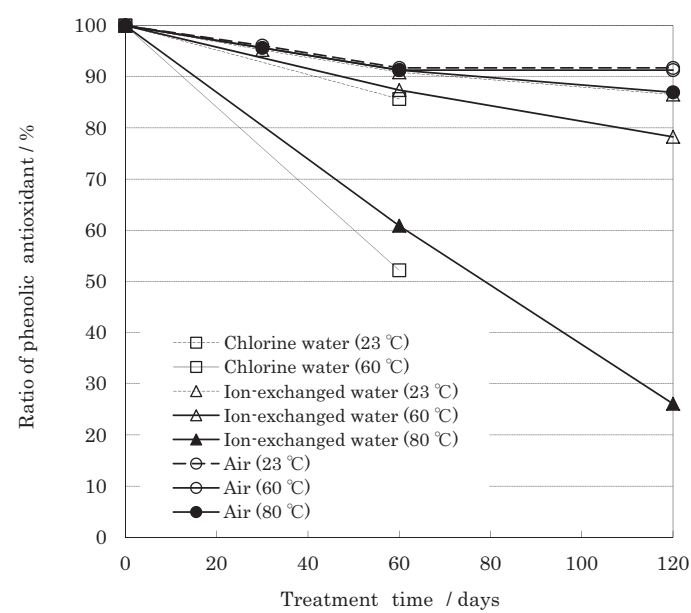

Figure 5 Residual ratio of phenolic antioxidant in PP

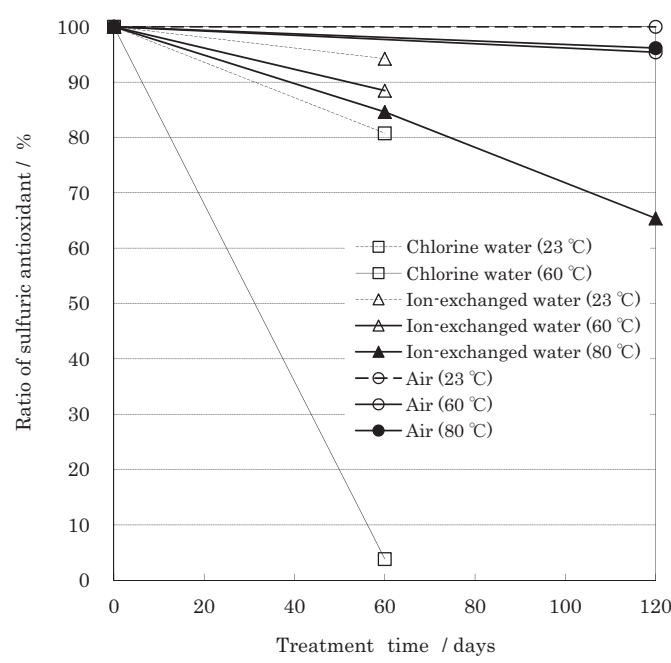

Figure 6 Residual ratio of sulfuric antioxidant in PP
費が主となり，過酸化物分解剂として消費される硫黄系に 比ベラジカル安定化剤として消費されるフェノール系で減 少が著しくなった。一方，イオン交換水による浸せき処理 において，酸化防止剤は熱酸化劣化防止による消費と水へ の溶出により減少するが，イオン交換水は不純物を含まず 溶解性の高い溶媒であるため酸化防止剂の溶出を促進し, 熱老化処理と比べ著しく減少したままた，塩素水による浸 せき処理ではイオン交換水よりも酸化防止剤の減少がさら に著しく, 水中への溶出に加えポリマー表面近傍に残存する 酸化防止剂は次覀塩素酸により生成したポリマーラジカルの 消滅や過酸化物の分解のために消費されたと考えられる.

イオン交換水による浸せき処理では硫黄系に比べフェノ 一ル系酸化防止剤の減少が大きく，塩素水による浸せき処 理では反対に硫黄系酸化防止剂の減少が大きい。この原因 として, 塩素水では次亜塩素酸イオンが消費されると処理 水がアルカリ性へと変化し, 酸化防止剤が溶出しやすくな ったこと, 残留塩素による劣化において過酸化物分解剂と しての硫黄系酸化防止剤がより多く消費されたことが推察 される。

\section{3 機械的特性及び動的粘弾性の評価}

塩素水，イオン交換水による浸せき処理及び熱老化処理 によるPP成形品の引張降伏応力の変化を Figure 7 に示 す. 熱老化処理及びイオン交換水による浸せき処理前後に おいて, 引張降伏応力に有意差は認められない。処理時間 の増加に伴い引張降伏応力が一端上昇を示すが，これは処 理時の熱により樹脂内で結晶性ポリマー特有の結晶化度の 増加による高次構造などの変化により成形時に生じた残留 応力が緩和され, さらには結晶分布の均一化が生ずるため, 引張降伏応力が上昇したものと考えられる。事実, DSC による処理前後の結晶の融解熱を測定したところ，処理後 では融解熱が大きくなった。一方， $60{ }^{\circ} \mathrm{C}$ の塩素水による 浸せき処理品において, 引張降伏応力は, 一端上昇後急激 に低下し激しい劣化ダメージを受けている。

曲げ試験の結果を Figure 8に示す。引張試験と同様に 熱老化処理及びイオン交換水による浸せき処理前後におけ る曲げ強さに有意差は認められないが， $60{ }^{\circ} \mathrm{C}$ の塩素水に よる浸せき処理において, Figure 7 で示した引張降伏応力 
の低下よりも早い処理後 30 日で曲げ強さが低下した。曲 げ試験は試料最上面に最大圧縮応力が発生し, 反対に最下 面に最大引張応力が発生するため, 試料表面の劣化を顕著 に反映する。一方，引張試験は一軸伸長時の弾性限界強度 を測定しており，劣化が進行していない試料内部の物性が 強く反映される。それ故引張降伏応力に比べ曲げ強さの低 下が早期に観察されたと考えられる。

一方，動的粘弾性の測定結果を Figure 9 に示すが，塩 素水，イオン交換水による浸せき処理及び熱老化処理のい ずれも処理時間の増加に伴う貯蔵弾性率及び損失正接のピ 一ク温度の著しい変化は認められず，試料全体の材料剛性 に与える影響はほとんどない。これは引張試験と同様に， 弾性領域における一軸方向への伸縮変形ではごく表面での 劣化の影響をほとんど受けないためである，また，塩素水処 理後において正接損失のピーク值がわずかに低下する傾向が あるが，これは吸水により水素結合が弱まり，分子間の自由 体積が増加し分子間摩擦が低減した結果と推察される。

以上より, 室温 $\left(23{ }^{\circ} \mathrm{C}\right), 60{ }^{\circ} \mathrm{C}, 80{ }^{\circ} \mathrm{C}$ の熱老化処理で は劣化による機械的強度の低下は見られず， $60{ }^{\circ} \mathrm{C}$ 及び 80 ${ }^{\circ} \mathrm{C}$ のイオン交換水による浸せき処理においては酸化防止剂

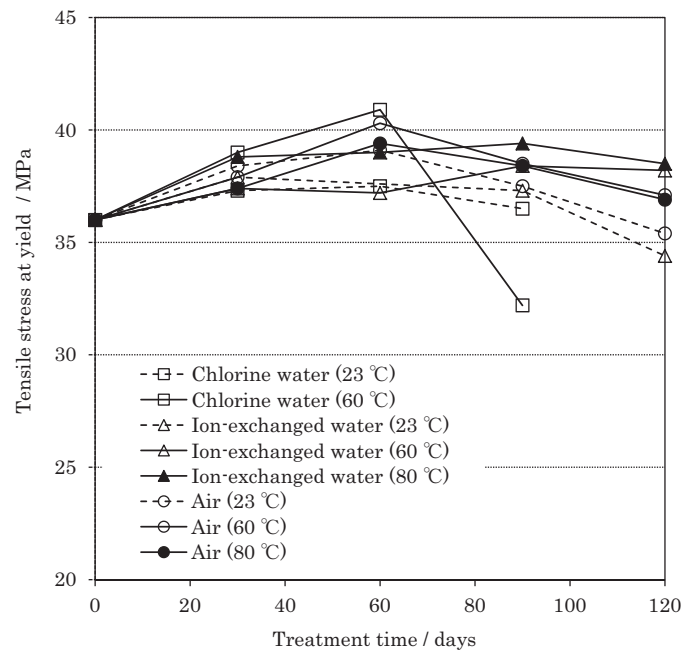

Figure 7 Change of tensile stress at yield against treatment times

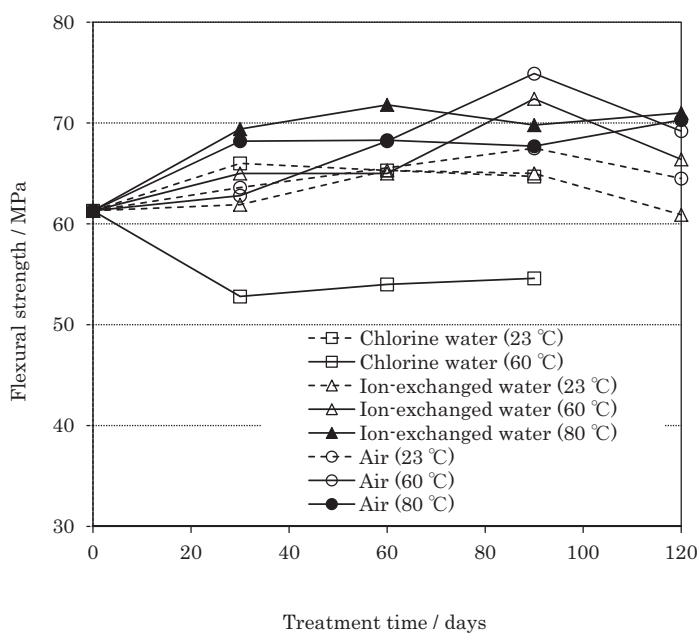

Figure 8 Change of flexural strength against treatment times
の減少が認められるもののポリマー中に酸化防止剤が残存 しており，顕著なポリマー劣化を生じていないため引張降 伏応力及び曲げ強さに変化は見られない。また， $60{ }^{\circ} \mathrm{C} の$ 塩素水による浸せき処理では，ポリマー中の酸化防止剂の 急激な減少とともに, 引張降伏応力及び曲げ強さが低下し た。この劣化現象は室温 $\left(23{ }^{\circ} \mathrm{C}\right)$ での浸せき処理では見 られず，熱による分子運動の活発化により水中への老化防 止剂の溶出が促進されたことが，著しい劣化を引き起こし た原因と考えらえる。

\section{4 顕微鏡 FT-IR（ATR 法）による表面劣化分析}

処理後, 風乾した試料表面は黄変し硫黄系酸化防止剂が ブルームしていることがFT-IRスペクトルから判明，こ の表面付着物を2-プロパノールでふき取った試料の FT-IR スペクトルを Figure 10 に示す. 熱老化処理品及びイオン 交換水による浸せき処理品はPP由来の吸収のみで劣化に よる吸収は認められず，さらに，室温 $\left(23{ }^{\circ} \mathrm{C}\right)$ の塩素水 による浸せき処理品も劣化に起因するスペクトルは認めら れないが， $60{ }^{\circ} \mathrm{C}$ の塩素水による浸せき処理品においては $\mathrm{PP}$ 由来の吸収の他に，1800〜 $1600 \mathrm{~cm}^{-1}$ 付近の吸収も認 められた。また， $1300 \mathrm{~cm}^{-1}$ 付近の C-Cl結合に由来する 吸収は確認されず，PPの塩素化は生じていないと推察さ れる. PPは酸化劣化により水酸基による $3400 \mathrm{~cm}^{-1}$ 付近 のブロードな吸収，カルボニル基による $1740 \mathrm{~cm}^{-1}$ 付近 の強い吸収，-C = C-による $1650 \mathrm{~cm}^{-1}$ 付近の吸収が出現 することが知られており, 次亜塩素酸及び次亜塩素酸イオ ンが PP表面を攻撃しカルボニル基及び $-\mathrm{C}=\mathrm{C}-$ が生成, 酸化 劣化が生じていることが確認された．親水基であるカルボ ニル基が生じることで，ポリマーの表面近傍は水分を吸着 しやすくなり，酸化防止剤の溶出とポリマー劣化を更に促 進した可能性がある。この表面及び表面近傍の酸化劣化が $\mathrm{PP}$ 成形品の機械的強度低下を引き起こしたと考えらえる。

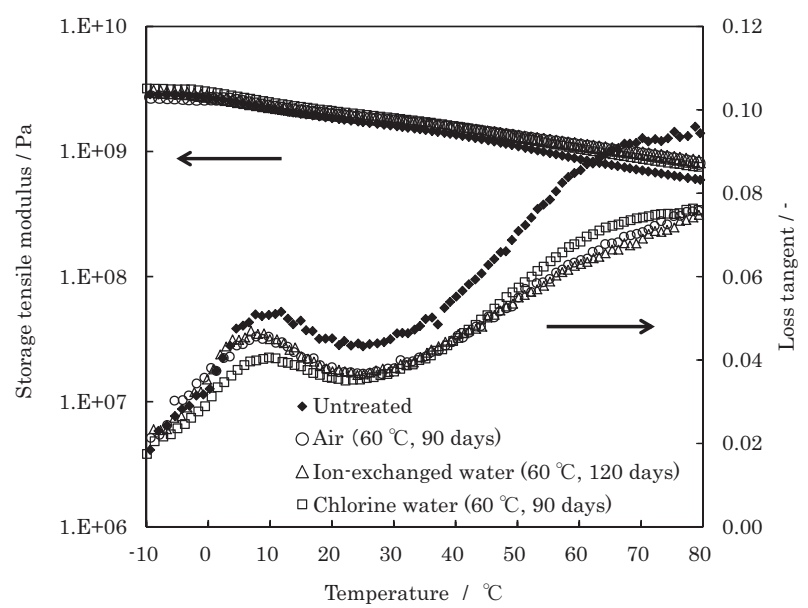

Figure 9 Temperature dependence of storage tensile modulus and loss tangent 


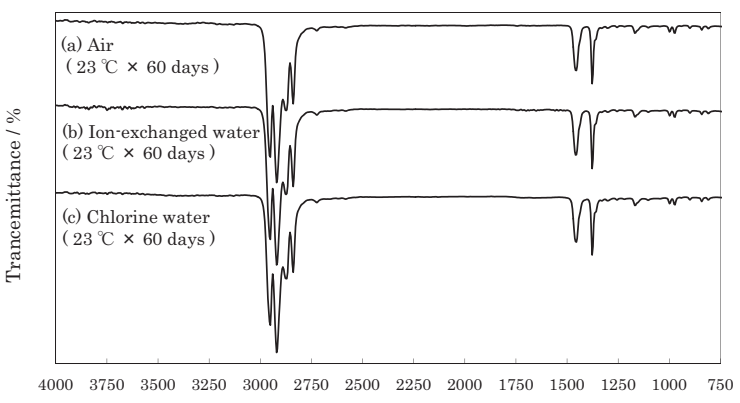

Wavenumber $/ \mathrm{cm}$

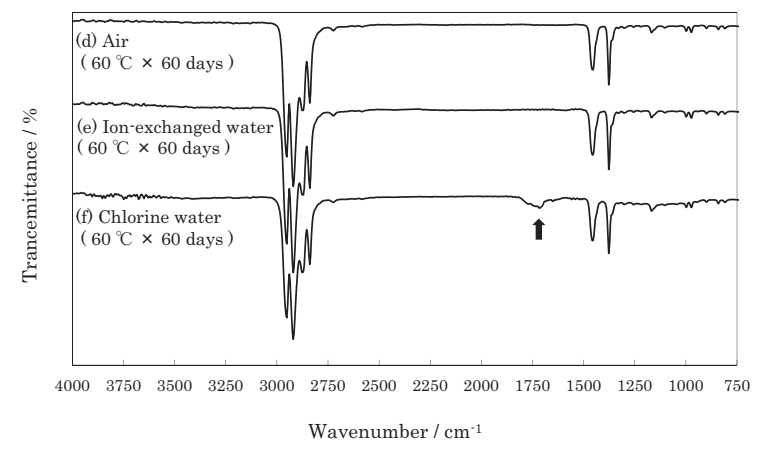

Figure 10 FT-IR spectra on the surface of PP after blooms were wiped off

\subsection{DSCによる酸化開始温度}

PPのようなポリオレフィン系材料は，酸化初期段階に て熱に不安定な過酸化物（R-O-O）が生成すると，酸化開 始温度は劣化過程に比例し低下傾向を示す ${ }^{6)}$ 。また，酸化 防止剂を含む場合は，耐酸化性向上のため初期の酸化開始 温度は上昇し，酸化防止剤含有量の減少に伴い酸化開始温 度は低下する。これらの現象を利用することでPPの酸化 劣化度合いを評価することができる，処理時間に対する酸 化開始温度の変化を Figure 11 に示す。熱老化処理では酸 化開始温度の低下は確認されず,酸化防止剤の減少がなく, 未劣化の結果と一致した。同様に，室温 $\left(23{ }^{\circ} \mathrm{C}\right), 60{ }^{\circ} \mathrm{C}$ のイオン交換水による浸せき処理では酸化開始温度の低下 は確認されないものの，80 ${ }^{\circ} \mathrm{C} ， 120$ 日処理後は酸化開始温 度が $18{ }^{\circ} \mathrm{C}$ 低下し，酸化防止剤の減少が顕著であった結果 と一致する。一方， $60{ }^{\circ} \mathrm{C}$ の塩素水による浸せき処理では, 酸化開始温度の著しい低下が認められ，これは酸化防止剂 の急激な減少と同時にポリマーの劣化が生じていることに 起因する．以上から，水中では空気中に比べ酸化防止剤の 溶出により酸化開始温度が下がり，酸化劣化しやすい状態 となって抢り，特に残留塩素存在下では，水中へ酸化防止 凨の著しい溶出と同時に劣化因子である残留塩素によるポ リマーの酸化劣化により, 酸化開始が著しく促進されるこ とが熱分析からも明瞭となった。

\section{4. 結}

\section{論}

フェノール系及び硫黄系酸化防止剂を添加したPP成形 品に，市場での使用を想定した塩素水による浸せき処理， イオン交換水による浸せき処理及び熱老化処理を実施し

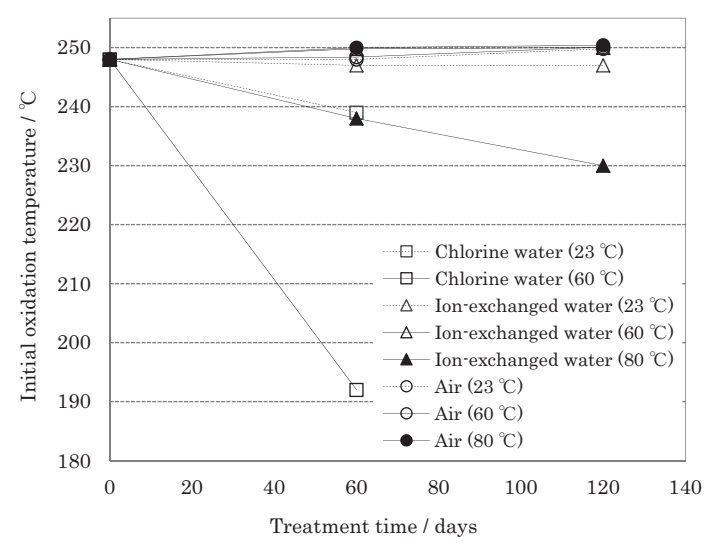

Figure 11 Change of initial oxidation temperature against treatment times

たそその結果，酸化防止剤を 5 倍量である $1.25 \mathrm{wt}$ \%添加 したPPでは浸せき処理において，分子量の比較的低い硫 黄系酸化防止剈のジオクタデシル 3,3'-チオジプロピオナー トが激しくブルームし，酸化防止剤 $0.25 \mathrm{wt} \%$ 添加したPP の浸せき処理では，熱老化処理に比べ溶出による酸化防止 片の急激な減少で著しく酸化開始が促進された．特に塩素 水による浸せき処理では，表面に酸化劣化を示すカルボニ ル基及び-C $=\mathrm{C}$-が生成，曲げ強さ，曲げ弾性率などの機 械的強度が顕著に低下した。

水道水環境下では水の介在によりポリマーの寿命を決定 づける酸化防止剤の流出が生じることから，水がポリマー を劣化させる直接の要因とはならないが，酸化劣化を容易 にし，表面劣化及びそれに伴う強度低下を生じさせ，PP 成形品を水道水環境下で使用した場合，空気中で使用する 場合に比べ著しく寿命が短くなる理由が判明した。

\section{References}

1 ) Maekawa, T.; Aoki, H.; Suzuki, T.: Zairyo, 22, 785 (1973)

2 ) Yamada, M.; Sugioka, Y.; Shin, H.; Amano, R. ; Ohtake, Y.: Nippon Gomu Kyokaishi, 81, 44 (2008)

3 ) Yamada, M.; Sugioka, Y.; Shin, H.; Ohtake, Y.: Nippon Gomu Kyokaishi, 82, 389 (2009)

4 ) Ohtake, Y.: The Society of Polymer Science, Japan, 58, 8 (2009)

5 ) Watanabe, T.: In “Gomu Kougyo Binran (4th ed.)", Nippon Gomu Kyokai Ed, Nippon Gomu Kyokai, Tokyo, p.425 (1994)

6 ) Nakayama, K.; Watanabe, T.; Ohtake, Y.; Furukawa, M.: Nippon Goти Kyokaishi, 81, 467 (2008)

\section{日本語表記参考文献}

1 ）前川健，青木弘行，鈴木邁：材料，22, 785（1973）

2 ) 山田美緒, 杉岡佳彦, 進博人, 天野良三, 大武義人：日本ゴム 協会誌，81, 44（2008）

3 ）山田美緒，杉岡佳彦，進博人，大武義人：日本ゴム協会誌，82, 389 (2009)

4 ）大武義人：高分子，58，8（2009）

5 ）渡辺隆：ゴム工業便覧（第4版），日本ゴム協会編，日本ゴム協 会, 東京, p.425（1994）

6 ) 仲山和海, 渡邊智子, 大武義人, 古川睦久：日本ゴム協会誌, 81,467 (2008) 